\title{
PEMBERDAYAAN MASYARAKAT DALAM PEMANFAATAN EKOSISTEM RAWA GAMBUT SECARA BERKELANJUTAN
}

\author{
Zulkarnaini dan Evawani Elysa Lubis \\ FISIP Universitas Riau, Kampus Bina Widya Km. 12,5 Simpang Baru Panam, Pekanbaru 28293
}

\begin{abstract}
Community Empowerment in Sustainable Use of Peat Swamp Ecosystems. Balai Jaya Subdistrict, Rokan Hilir Regency is an area that is included in the red zone of forest and land fires in Riau Province. Whereas the existence of this area is very strategic in the maintenance of wetland ecosystems because part of the area is peat swamp forest. If the utilization of the peat swamp ecosystem is not done wisely, it will cause damage to the ecosystem and resources contained therein, while at the same time reducing the welfare of the people who depend on the ecosystem. The purpose of this study is to analyze the pattern and strategy of community empowerment in the utilization of peat swamp ecosystem in Balai Jaya District, Rokan Hilir Regency. This research is a type of qualitative approach with the sampling technique used is snowball sampling. The research informants were the officers involved in the community empowerment program at the research location. Data collection was carried out with interview and observation techniques, after the data was collected and analyzed using qualitative descriptive analysis. The results of the study indicate that the importance of empowerment efforts with the main goal is to improve the quality of life of the community. This is because that community empowerment is believed to motivate to change towards a better direction so as to improve the family's socio-economy, foster a work culture, and foster the spirit to cooperate. Education and counseling topics that are needed by the community on peatlands are environmental education, the application of environmentally friendly technologies, and the socialization of regulations related to ecosystem protection.
\end{abstract}

\begin{abstract}
Abstrak: Pemberdayaan Masyarakat dalam Pemanfaatan Ekosistem Rawa Gambut Secara Berkelanjutan. Kecamatan Balai Jaya Kabupaten Rokan Hilir merupakan daerah yang termasuk dalam zona merah kebakaran hutan dan lahan di Provinsi Riau. Padahal keberadaan daerah ini sangat strategis dalam pemeliharaan ekosistem lahan basah karena sebagian wilayahnya adalah hutan rawa gambut. Bila pemanfaatan ekosistem rawa gambut tidak dilakukan secara bijaksana, maka akan menyebabkan kerusakan ekosistem dan sumberdaya yang terdapat didalamnya, sekaligus akan menurunkan kesejahteraan masyarakat yang bergantung pada ekosistem tersebut. Tujuan penelitian ini menganalisis pola dan strategi pemberdayaan masyarakat dalam pemanfaatan ekosistem rawa gambut di Kecamatan Balai Jaya Kabupaten Rokan Hilir. Penelitian ini merupakan jenis pendekatan kualitatif dengan teknik penarikan sampel yang digunakan adalah snowball sampling. Informan penelitian adalah aparat yang terlibat dalam program pemberdayaan masyarakat di lokasi penelitian. Pengumpulan data dilakukan dengan tehnik wawancara dan observasi, setelah data terkumpul kemudian dianalisa dengan menggunakan analisa deskriptif kualitatif. Hasil penelitian menunjukkan bahwa penting adanya usaha pemberdayaan dengan sasaran utama adalah peningkatan kualitas hidup masyarakat. Hal ini dikarenakan bahwa pemberdayaan masyarakat diyakini dapat memotivasi untuk berubah ke arah yang lebih baik sehingga meningkatkan sosial ekonomi keluarga, menumbuhkan budaya kerja, serta memupuk semangat untuk bekerjasama. Topik pendidikan dan penyuluhan yang diperlukan masyarakat di lahan gambut adalah pendidikan lingkungan, penerapan teknologi ramah lingkungan, dan sosialisasi peraturan yang berhubungan dengan perlindungan eksosistem.
\end{abstract}

Kata Kunci: pemberdayaan masyarakat, perlindungan ekosistem, lahan gambut berkelanjutan

\section{PENDAHULUAN}

Masyarakat yang tinggal di sekitar ekologi lahan basah mempunyai ketergantungan yang sangat besar terhadap ekosistem setempat. Karena itulah keberadaan mereka dapat berperan ganda: sebagai penjaga sekaligus perusak dari ekosistem tersebut. Untuk itu perlu dibangun suatu pola pengelolaan ekosistem yang melibatkan semua pihak, sehingga mas- yarakat dapat merasakan manfaatnya secara nyata, dan seterusnya keberadaan mereka diharapkan dapat menjaga ekosistem tersebut (Pramana, 2012). Tujuannya adalah agar masyarakat ikut memiliki kepentingan untuk menggunakan segala sumber daya yang tersedia secara bertanggung jawab dan berkesinambungan.

Aktivitas pemanfaatan ekosistem pada 
beberapa kawasan lahan basah di Indonesia memang memprihatinkan karena seringkali dilakukan secara eksploitatif dan destruktif. Akibatnya laju kerusakan (degredasi) lahan tidak dapat terhindarkan. Fenomena degredasi lahan ini terus berlangsung sampai sekarang, bahkan disinyalir telah memicu terjadinya kebakaran hutan dan lahan yang besar di Indonesia pada umumnya dan Provinsi Riau pada khususnya, terutama dalam rentang waktu 5 tahun terkahir (2013-2017).

Di Kabupaten Rokan Hilir Provinsi Riau pada kurun waktu tersebut kebakaran hutan dan lahan terutama kawasan rawa gambut hampir terjadi sepanjang tahun. Tahun 2013 terjadi kebakaran 20 Ha yang merupakan areal perkebunan kelapa sawit. Berikutnya tahun 2014 sedikitnya 250 Ha lahan gambut yang masing kosong ludes dilalap si jago merah. Lahan kosong tersebut diduga kuat sengaja dibakar dan kemungkinan akan ditanami kelapa sawit. Tahun 2015 terjadi peningkatan kebakaran lahan gambut menjadi $100 \mathrm{Ha}$. Selanjutnya tahun 2016 kondisi kebakaran lahan semakin parah karena areal yang terbakar mencapai 75 Ha. Dan tahun 2017, walaupun peristiwa kebakaran agak sedikit mereda, namun tidak kurang 30 Ha lahan gambut habis dilalap api.

Pemanfaatan secara eksploitatif ini telah menyebabkan ekosistem mengalami kehancuran yang secara kuantitas dan kualitas akan menurunkan fungsi sosial, ekologis mapun ekonomis. Apalagi dengan banyaknya kepentingan dari berbagai pihak yang memanfaatkan ekosistem sering menimbulkan konflik dan mengarah pada pengelolaan dengan pertimbangan sempit. Kondisi ini diperparah lagi dengan tidak adanya perhatian dan kegiatan nyata terhadap pengelolaan ekosistem yang dilakukan oleh pemerintah maupun LSM, yang membuat pemanfaatan ekosistem ini menjadi sangat membahayakan keberlanjutan kehidupan masyarakat pada masa mendatang.

Suratmo, dkk (2015) menyebutkan, dalam konteks berkelanjutan pengelolaan ekosistem rawa gambut di cagar biosfer, maka aspek pencegahan kebakaran merupakan hal penting dan lebih utama untuk dilakukan sebagai tindakan awal karena jauh lebih baik daripada melakukan proses pemadaman. Hal ini dikarenakan proses pemadaman api dan rehabilitasi pasca terbakar akan membutuhkan biaya dan waktu sangat besar nilanya. Untuk itu, kegiatan pencegahan kebakaran harus terus-menerus atau berkelanjutan dilakukan, karena merupakan cara yang lebih ekonomis untuk mengurangi kerusakan dan kerugian yang ditimbulkan.

Bila pengelolaan ekosistem rawa gambut ini tidak dilakukan secara bijaksana, maka akan menyebabkan kerusakan ekosistem itu sendiri dan sumberdaya yang terdapat didalamnya sekaligus akan menurunkan kesejahteraan masyarakat yang bergantung pada ekosistem tersebut (Gunarso, dkk, 2013). Maka perlu adanya usaha pemberdayaan dengan sasaran utama adalah peningkatan kualitas hidup masyarakat. Hal ini dikarenakan bahwa pemberdayaan masyarakat diyakini dapat memotivasi untuk berubah ke arah yang lebih baik, sehingga meningkatkan sosial ekonomi keluarga, menumbuhkan budaya kerja, serta memupuk semangat untuk bekerjasama (Rohmah, 2014).

Pola pengembangan kelembagaan masyarakat yang dibutuhkan pada masa sekarang adalah menjunjung tinggi aspirasi dan potensi masyarakat untuk melakukan kegiatan swadaya (Permatasari, 2014). Bentuknya berupa intervensi bottom-up yang menghormati dan mengakui bahwa masyarakat bawah memiliki potensi untuk memenuhi kebutuhannya, memecahkan masalah, dan dapat melakukan usaha produktif dengan prinsip swadaya dan kebersamaan (Sulistiyani, 2004). Dari pemikiran ini dapat dinyatakan, baik buruknya ekosistem tidak terlepas dari masyarakat yang berdiam di kawasan tersebut, artinya masyarakatlah yang memiliki peranan penting bagi kelestarian ekosistem rawa gambut tersebut.

Berdasarkan pemikiran diatas, maka perlu dilakukan kegiatan serta kajian untuk memberi gambaran menyeluruh tentang konsep dan strategi pemberdayaan masyarakat di lahan gambut yang diintegrasikan dengan 
tujuan pelestarian lingkungan. Kegiatan tersebut tentunya membahas uraian mengenai ekosistem lahan gambut dan permasalahannya untuk memperoleh kesepahaman tentang pentingnya menjaga sumberdaya alam ini dari kerusakan. Kegiatan yang dilakukan perlu juga dirangkai dengan pemaparan rinci tentang strategi pemberdayaan masyarakat, serta hikmah yang diperoleh dari pengalaman memberdayakan masyarakat tersebut.

\section{METODE}

Penelitian ini merupakan jenis pendekatan kualitatif dengan teknik penarikan sampel yang digunakan adalah snowball sampling. Informan penelitian adalah aparat yang terlibat dalam program pemberdayaan masyarakat di lokasi penelitian. Pengumpulan data dilakukan dengan tehnik wawancara dan observasi, setelah data terkumpul kemudian dianalisa dengan menggunakan analisa deskriptif kualitatif. Untuk tercapaian tujuan yang diharapkan, maka dilakukan langkah-langkah: Pertama, mengidentifikasi dan memahami tentang kondisi-kondisi yang ada (das sein). Berupaya mengidentifikasi dan memahami tentang kondisi-kondisi yang ada pada lokasi pengabdian tersebut secara keseluruhan. Aturan dan pedoman komponen-komponen dan faktorfaktor yang sesuai dengan model, serta menganalisa pola pemberdayaan masyarakat di ekosistem rawa gambut. Kedua, Mengidentifikasi tentang kondisi yang diinginkan (das dollen). Berisi berbagai faktor yang mungkin perlu perubahan dan perkembangannya dengan catatan perubahan yang diinginkan itu disesuaikan dengan kebutuhan masyarakat dan kondisi yang diinginkan harus keadaan yang mungkin dapat dicapai.

\section{HASIL DAN PEMBAHASAN}

Mata pencaharian penduduk desa di Kecamatan Balai Jaya umumnya masih terkait dengan subsistem pertanian, terutama perkebunan sawit dan karet, perikanan, dan sebagian kecil perdagangan. Masyarakat lokal berkebun kelapa sawit baru diintroduksi beberapa puluh tahun terakhir ini oleh para pendatang yang umumnya berasal dari etnis Batak dan Jawa lebih memilih menanam sawit dengan luas berkisar antara 2-3 Ha. Oleh karenanya, masyarakat berkepentingan untuk memenuhi kebutuhan hidup dan meningkatkan kesejahteraannya dengan bergantung pada kawasan perkebunan. Perkebunan terdiri dari perkebunan milik perusahaan dan perkebunan milik masyarakat. Sebagian kecil lahan perkebunan tersebut berada di lahan basah (gambut).

Kelapa sawit merupakan komoditas paling banyak produksinya. Total luas tanaman kelapa sawit mencapai 47.301,40 Ha yang menghasilkan 114.845,28 ton CPO. Sedangkan tanaman karet seluas 1.351,00 Ha dan menghasilkan 1.035,14 karet kering. Kakao seluas 3,00 Ha menghasilkan 0,53 ton biji kering kakao. Namun kecamatan ini tidak termasuk daerah potensi pertanian tanaman pangan maupun palawija karena lahan sebagian besarnya adalah lahan bukan lahan sawah. Walaupun semua pertanian tanaman pangan dapat dihasilkan, namun jumlahnya tidak terlalu besar. Luas panen jagung mencapai 202 Ha dengan produksi jagung mencapai 452,48 ton. Di kecamatan ini juga cukup banyak ditemukan usaha peternakan. Jumlah sapi tahun 2015 mencapai 3.121 ekor dan kambing/domba 668 ekor. Selain itu juga terdapat peternak/usaha ayam buras/kampung mencapai 6.192 ekor dan itik 671 ekor.

Fasilitas perekonomian berskala kecil cukup tersedia di setiap desa/kelurahan, walaupun masih ada desa yang belum memiliki pasar sendiri. Atas kondisi demikian, maka penduduk desa/kelurahan yang wilayahnya tidak tersedia pasar atau kelompok pertokoan harus mengunjungi desa/kelurahan lain yang tersedia pasar apabila ingin melakukan transaksi ekonomi di pasar. Jumlah restoran / rumah makan ada 27 unit, warung makan 641 unit hotel/penginapan 1 unit, warung kelontong 263 unit yang terdapat di semua desa/kelurahan, pasar permanen sudah ada 7 unit dan pasar tanpa bangunan 2 unit.

Infrastruktur yang tersedia masih sangat terbatas. Ketersediaan infrastruktur seperti jalan, listrik, pasar ataupun perbankan masih 
kurang untuk mendukung aktivitas kehidupan masyarakat sehari-hari. Di beberapa desa, kurangnya infrastruktur yang tersedia telah mendorong inisiatif penduduk untuk membangun infrastruktur dengan kondisi dan kualitas seadanya. Misalnya saja di beberapa desa, seperti Bagan Bakti dan Balam Jaya, penduduk telah berhasil membangun pasar yang beroperasi seminggu sekali dengan difasilitasi dan barang dagangan dijual oleh pedagang dari luar desa.

Masyarakat di lahan gambut sebenarnya hidup dalam ekosistem yang rapuh, termasuk di Kecamatan Balai Jaya. Karena rapuh dan marjinalnya lahan gambut inilah yang menyebabkan sebagian besar masyarakat mengalami kemiskinan. Antara kemiskinan dan ekosistem yang rusak ibarat dua sisi mata uang yang tidak bisa dipisahkan. Kita dapat saja mengatakan minimnya teknologi, pendidikan petani rendah, dan segudang alasan klasik lainnya yang menyebabkan mereka miskin, namun fakta hari ini menyebutkan bahwa ternyata belum banyak orang yang memberikan perhatian terhadap keberdayaan mereka.

Masyarakat di lahan gambut umumnya berada di lokasi yang jauh dari pusat perekonomian di Kecamatan Balai Jaya. Dari 14 desa/kelurahan yang ada, 3 desa yang memiliki lahan gambut cukup luas, memang jaraknya jauh dari ibukota kecamatan apalagi ibukota kabupaten. Desa Balam Jaya yang memiliki gambut terluas di Kecamatan Balai Jaya, jaraknya mencapai $18 \mathrm{KM}$ ke ibukota kecamatan dan 133 KM ke ibukota kabupaten, Desa Balam Sempurna Jaya berjarak 11 KM ke ibukota kecamatan dan $135 \mathrm{KM}$ ke ibukota kabupaten, dan Balam Sempurna berjarak 14 KM ke ibukota kecamatan dan 120 KM ke ibukota kabupaten.

Diperlukan biaya yang relatif besar bagi masyarakat ketiga desa untuk mencapai pusatpusat pertumbuhan ekonomi terdekat. Dampaknya adalah harga kebutuhan pokok dan sarana produksi pertanian menjadi lebih tinggi akibat biaya transportasi mahal. Selain itu, mahalnya biaya transportasi ini, juga menyebabkan sulitnya menjangkau layanan pemerintah seperti layanan kesehatan, pendidikan, dan informasi. Akibatnya sekalipun penghasilan petani terkadang meningkat, nilainya lebih rendah dan biaya hidup menjadi lebih tinggi karena tingginya harga kebutuhan pokok serta biaya pendidikan dan kesehatan.

Kondisi eksisting masyarakat tersebut membutuhkan perhatian yang mutlak bagi semua pihak. Tindakan yang mendesak perlu dilakukan adalah kegiatan pemberdayaan. Pemberdayaan masyarakat diharapkan dapat meningkatkan kemampuan masyarakat dalam mengoptimalkan pemanfaatan potensi ekonomi dan sumberdaya alam tanpa merusak lingkungan. Keterbatasan daya dukung ekonomi lahan gambut dari sisi pertanian, harus menjadi tantangan dalam mencari solusi agar masyarakat memiliki pilihan sumber penghidupan yang layak dan ramah lingkungan. Dengan demikian, peningkatan kemampuan ekonomi juga harus disertai dengan peningkatan kesadaran terhadap kelestarian lingkungan. Tanpa hal itu, peningkatan kondisi ekonomi justru dapat berbalik menjadi faktor perusak karena dapat menjadi modal bagi sebagian masyarakat yang tidak sadar untuk lebih banyak lagi melakukan kerusakan lingkungan.

Pelaku usaha di pedesaan lahan gambut, terutama petani pada umumnya, melakukan usaha secara subsistem. Mereka belum dapat mengembangkan budaya memupuk modal. Pada musim-musim panen, mereka memang kerap mengalami surplus produksi. Namun sebagian besar masih dihabiskan untuk membeli asset-aset yang tidak produktif yang bersifat konsumtif, akibatnya mereka hampir selalu kesulitan modal setiap kali akan mengawali proses produksi. Bila dihitung hanya berkisar 5-10\% pendapatan yang dialokasikan kembali untuk modal usaha, sedangkan sisanya untuk konsumsi dan membeli aset non produktif tadi. Mereka juga jarang menjual hasil produksinya ke pasar karena memang pasar yang permanen tidak ada, kalau pasar diibukota kecamatan jaraknya jauh dari tempat tinggal. Hasil produksi disimpan untuk konsumsi sendiri, akibatnya perputaran modal menjadi semakin terbatas. 
Rendahnya produksi dan tingkat perekonomian menjadi salah satu indikator dari rendahnya kompetensi sumberdaya manusia masyarakat desa di lahan gambut. Kondisi ini didukung oleh minimnya akses terhadap informasi dan teknologi baru. Sulitnya mengakses pengetahuan atau keterampilan dari para ahli atau praktisi membuat mereka hanya menggantungkan pada proses trial and error (coba-coba). Proses ini tidak hanya mengakibatkan lambatnya perkembangan kemampuan mereka, melainkan juga tidak mampu mengantisipasi kondisi lingkungan lahan gambut yang rentan.

Ditambah lagi dalam kondisi subsistem, petani tidak memiliki “pengaman”, sehingga rentan terhadap gejolak yang terjadi dalam hidupnya. Ketika sakit berat, mereka tidak memiliki tabungan yang cukup untuk berobat. Ketika gagal panen secara massal, desa menjadi rawan pangan. Jika hal ini terjadi berulang, masyarakat menjadi semakin tidak berdaya dan kemiskinan pun semakin dalam. Nyatanya lagi tingkat kesadaran masyarakat untuk menyisihkan sebagian pendapatan untuk kegiatan produktif masih sangat rendah. Mereka tidak menyadari bahwa pola pengeluaran semacam itu merupakan salah satu faktor yang menyebabkan kondisinya terus terpuruk dan terkungkung dalam belenggu kemiskinan.

Secara garis besarnya dapat dikatakan pentingnya pemberdayaan masyarakat di lahan gambut memiliki dua pertimbangan. Pertama, karena kemiskinan dan ketidakberdayaan yang dialami oleh sebagian besar masyarakat di lahan gambut. Kondisi ini seringkali menjadi penyebab ketidakpedulian mereka terhadap kualitas lingkungan. Kedua, upaya penyadaran dan penumbuhan motivasi untuk berpartisipasi dalam konservasi lahan terbukti sulit dilakukan apabila kebutuhan dasar masyarakat masih belum terpenuhi. Kedua hal di atas didasari kenyataan bahwa masyarakat miskin dan terbelakang adalah ketidaktersediaan peluang ekonomi dan mata pencaharian yang berkelanjutan. Karena itu, pemberdayaan masyarakat di lahan gambut harus dapat meningkatkan kemampuan masyarakat dalam meng- optimalkan pemanfaatan potensi ekonomi dan sumber daya alam tanpa merusak lingkungan.

Keterbatasan daya dukung ekonomi lahan gambut dari sisi pertanian, harus menjadi tantangan dalam mencari potensi lain agar masyarakat memiliki pilihan sumber penghidupan yang layak dan ramah lingkungan. Dengan demikian, peningkatan kemampuan ekonomi juga harus disertai dengan peningkatan kesadaran terhadap kelestarian lingkungan. Tanpa hal itu, peningkatan kondisi ekonomi justru dapat berbalik menjadi faktor perusak karena dapat menjadi modal bagi sebagian masyarakat yang tidak sadar untuk lebih banyak lagi melakukan kerusakan lingkungan.

Gambut merupakan sumber daya alam yang unik, memiliki peran yang kompleks dan sifat fragil. Kondisi itu sebenarnya menjadi peluang bagi tumbuhnya beragam partisipasi masyarakat sekaligus kesempatan kerja dan berusaha. Berikut beberapa bentuk partisipasi dan kegiatan yang berpeluang menciptakan kesempatan kerja dan peluang usaha yang memungkinkan dilakukan oleh masyarakat di lahan gambut.

a. Partisipasi dalam menanggulangi kebakaran lahan

Kebakaran lahan gambut sangat mudah meluas dan menimbulkan dampak yang sangat merisaukan. Untuk menanggulangi permasalahan tersebut, pemerintah dihimbau memiliki satuan pemadam kebakaran lahan dan hutan. Dalam hal, ini masyarakat yang berada di sekitar lahan gambut dapat berperan sebagai anggota satuan pemadam kebakaran di tingkat desa seperti yang dilakukan. Tim ini selain memiliki struktur organisasi yang jelas, ia juga diberikan tehnik pelatihan pencegahan dan pemadaman api, termasuk cara-cara menggunakan peralatan pemadaman kebakaran milik pemerintah, sehingga ia senantiasa siap dilibatkan pada setiap kegiatan pemadaman kebakaran.

b. Partisipasi dalam kegiatan rehabilitasi lahan Upaya rehabilitasi hutan memerlukan tenaga kerja yang cukup banyak terutama di bidang 
pembibitan tanaman, penanaman, dan pemeliharaan. Masyarakat di lahan gambut dapat mengambil peran dalam kegiatankegiatan semacam itu. Peningkatan keterampilan teknis dan manajemen, permodalan, serta mediasi dengan sektor-sektor tekait dan mitra kerja lain, sangat diperlukan oleh masyarakat agar mereka dapat mengisi kesempatan kerja tersebut. Namun dari kegiatan ini dapat ditarik suatu proses pembelajaran yang berarti dimana masyarakat dapat dilibatkan untuk ikut berpartisipasi dalam melestarikan lingkungan dan meningkatkan kesadaran mereka bahwa kecerobohan dalam menggunakan api berdampak parah terhadap kerusakan hutan dan sangat sulit untuk diperbaiki.

c. Pemanfaatan lahan melalui agroforestry Sistem agroforestry yang saat ini sedang gencar dikembangkan oleh pemerintah akan membuka kesempatan kerja petani untuk meningkatkan optimalisasi pemanfaatan lahan hutan (gambut) bagi komoditas pertanian yang lebih produktif dengan system wanatani. Di samping itu, perkebunan swasta di lahan gambut dangkal, membuka peluang kerja bagi masyarakat terutama petani di sekitar perkebunan.

d. Pemanfaatan lahan melalui Usaha Tani Terpadu

Usaha tani terpadu seperti tanaman pangan, perkebunan, kehutanan, perikanan, dan peternakan, yang berkelanjutan cukup berpeluang untuk dikembangkan di lahan gambut. Hal ini dimungkinkan karena sebagian lahan gambut (khususnya yang dangkal) merupakan lahan yang sesuai bagi pengembangan berbagai komoditas pertanian. Tanaman kehutanan dan perkebunan dapat dipanen dalam jangka panjang. Sementara tanaman pangan dan hortikultura dapat dipanen dalam jangka pendek. Perairan di lahan gambut dapat dimanfaatkan untuk budidaya perikanan. Demikian pula, komoditas ternak seperti ayam, itik, kerbau, dan sapi dapat dipelihara untuk cash income atau tabungan. Sementara kotoran ternak tersebut dapat digunakan sebagai pupuk atau bahan pembuat kompos.
Untuk mewujudkan ekosistem rawa gambut terhindar dari kerusakan karena termanfaatan secara berlebihan diperlukan dukungan semua pihak. Karena itu penting dilakukan upaya penyelarasan kebijakan dan penguatan kelembagaan masyarakat sebagai pemanfaat kawasan. Untuk masyarakat sekitar diperlukan peningkatan pengetahuan melalui proses pembinaan sehingga mereka bisa berdaya dan berkontribusi secara berkesinambungan.

Pemanfataan ekosistem lahan gambut, tujuan pemberdayaan tidak semata-mata peningkatan kesejahteraan rakyat. Ide dasarnya adalah terciptanya keseimbangan antara keberdayaan masyarakat dan pelestarian lingkungan. Pelestarian lingkungan dalam hal ini, tidak semata-mata untuk memenuhi kepentingan masyarakat secara umum tetapi juga dimaksudkan bagi kelangsungan hidup dan kehidupan masyarakat di kawasan lahan gambut. Tanpa lingkungan yang dapat menjamin kehidupan dan penghidupan yang layak, keberdayaan masyarakat di lahan gambut sulit untuk diwujudkan. Dengan kata lain, keberdayaan harus dicapai melalui peningkatan kapasitas dan masyarakat serta kelestarian lingkungannya. Oleh sebab itu, pemberdayaan masyarakat di lahan gambut ditujukan untuk membangun motivasi, partisipasi, dan kontribusi masyarakat dalam hal pemenuhan kebutuhan hidup dan pelestarian lingkungan. Aktivitas tersebut harus merupakan tindakan sistematis dan terencana yang dimaksudkan untuk mengembangkan kapasitas dan kompetensi masyarakat agar mampu menolong dirinya sendiri sehingga secara mandiri mampu memenuhi kebutuhan hidupnya sekaligus mampu menjaga lingkungannya dengan penuh kesadaran.

Pelaksanaan kegiatan pemberdayaan masyarakat memerlukan "pendampingan", yaitu kegiatan memfasilitasi proses pembelajaran secara nonformal untuk mencapai keberdayaan masyarakat. Selama proses pendampingan, masyarakat belajar, berlatih sambil bekerja (on the job training), dan berlatih terus-menerus (on going process) seiring dengan perkembangan kegiatan pemberdayaan. Dalam proses tersebut mereka akan ber- 
kembang, semakin berdaya, dan memperoleh pengetahuan serta keterampilan dari pengalamannya.

Tujuan pendampingan pada dasarnya mencakup dua elemen pokok, yaitu tumbuhnya kemandirian dan partisipasi aktif masyarakat. Pertama, kemandirian merupakan kemampuan untuk pelepasan diri dari keterasingan, atau kemampuan untuk bangkit kembali pada diri manusia yang mungkin sudah hilang karena adanya ketergantungan, exploitasi, dan sub ordinasi. Kemandirian merupakan cermin adanya kepercayaan seseorang pada kemampuan sendiri yang menjadi suatu kekuatan pendorong untuk kreativitas manusia, otonomi untuk mengambil keputusan, bertindak berdasarkan keputusan sendiri, dan memilih arah tindakan yang tidak terhalang oleh pengaruh luar seperti keinginan orang lain.

Kedua, partisipasi merupakan proses aktif dalam pelaksanaan kegiatan dan pengambilan keputusan yang dibimbing oleh cara berpikir masyarakat sendiri, sehingga mereka dapat melakukan kontrol efektif. Partisipasi aktif merupakan proses pembentukan kekuatan untuk keluar dari masalah yang bertolak dari kemampuan memutuskan, bertindak, dan berefleksi atas tindakan mereka sebagai subyek yang sadar. Berbeda dengan partisipasi aktif, dalam partisipasi pasif, masyarakat dilibatkan dalam tindakan yang telah dipikirkan, dirancang, dan dikontrol oleh orang lain.

Setelah jangka waktu tertentu, masyarakat dianggap sudah mencapai tahap mandiri sehingga proses pemberdayaan harus diakhiri. Namun demikian, pendamping harus yakin bahwa proses pemberdayaan akan terus berlanjut meskipun masyarakat tidak lagi didampingi. Dalam hal ini, kelompok harus dapat secara mandiri menjadi pendamping bagi masyarakat. Kriteria masyarakat yang sudah mandiri sehingga pendampingan perlu diakhiri antara lain: a) Masyarakat sudah sadar bahwa proses kapasitasi (animasi dan fasilitasi) dari orang luar (pendamping) tidak dibutuhkan lagi; b) Kelompok masyarakat dampingan sudah mandiri dan mampu bertindak sebagai pendamping bagi anggotanya (pendamping in- ternal), dan c) Kelompok sudah mampu menjadi fasilitator bagi kegiatan usaha dan pelestarian lingkungan yang dilakukan oleh anggota.

\section{SIMPULAN}

Kebutuhan pelestarian lahan gambut dari kerusakan bisa dikatakan “dibiayai” oleh kemiskinan dan keterbelakangan masyarakat di sekitar di lahan gambut itu sendiri. Oleh sebab itu, semua pihak berkepentingan dalam bentuk yang berbeda memberikan “imbalan” kepada mereka yang hidup dalam kemiskinan demi terjaganya kelestarian lahan gambut. Jika masyarakat luas dapat menikmati hidup karena ekosistem lahan gambut terjaga oleh petani yang miskin, berapakah yang sudah mereka kembalikan atau bayar dan insentif apa yang diterima oleh masyarakat jika mereka dapat menjaga lahan gambut. Semua pihak harus memberikan perhatian yang utuh kepada masyarakat yang telah menjaga ekosistem lahan gambut melalui kegiatan pemberdayaan. Pemberdayaan masyarakat di lahan gambut harus dibiayai oleh setiap orang yang menikmati manfaat langsung maupun tidak langsung atas ketidakrusakan lahan itu. Pemberdayaan masyarakat tersebut perlu dimulai oleh sebuah pemahaman bersama bahwa kesejahteraan petani gambut adalah demi kelangsungan hidup dan kemakmuran seluruh isi bumi. Kerja besar tersebut juga harus dibangun dalam sudut pandang yang lebih besar, yaitu menyadarkan masyarakat luas dan dunia agar peduli terhadap kelangsungan ekosistem lahan gambut, sama persis seperti tanggung jawab yang diberikan kepada masyarakat itu sendiri dalam menjaga ekosistem lingkungannya.

\section{DAFTAR RUJUKAN}

Huraerah, Abu. 2011. Pengorganisasi dan Pengembangan Masyarakat: Model dan Strategi Pembangunan Berbasis Kerakyatan. Bandung: Humaniora IKAPI.

Darmawan, Budi. 2015. Rancang Bangun Model Pencegahan Kebakaran Ekosistem Hutan Rawa Gambut. Pekanbaru: Pascasarjana Universitas Riau. 
Kartika, Ray Septianis. 2012. Partisipasi Masyarakat dalam Mengelola Alokasi Dana Desa (ADD) di Desa Tegeswetan dan Desa Jangkrikan Kecamatan Kepil Kabupaten Wonosobo. Jurnal Bina Praja, Vol. 4 No. 3.

Najiyati, Sri., Agus A., I Nyoman N.S., 2005. Pemberdayaan Masyarakat di Lahan Gambut. Bogor: Wetlands International. Noor, Muhammad. 2001. Pertanian Lahan Gambut; Potensi dan Kendala. Yogyakarta: Kanisius.

Noor, Muhammad. 2016. Lahan Gambut; Pengembangan, Konservasi, dan Perubahan Iklim. Yogyakarta: Gadjah Mada University Press.

Nugrianti, Oni dan Zulkarnaini. 2013. Pemberdayaan Masyarakat Melalui Program Alokasi Dana. Jurnal Kebijakan Publik. Vol. 4, No. 1

Pranarka dan Onny S. Prijono., 1996., Pemberdayaan: Konsep, Kebijakan dan Implementasi., Jakarta: CSIS.

Pramana Y. 2012. "Bentuk dan Tingkat Partisipasi Stakeholder dalam Pengelolaan Cagar Biosfer Giam Siak Kecil-Bukit Batu Provinsi Riau”. Tesis. Bogor: Institut Pertanian Bogor.

Rohmah, Siti. 2014. "Model Pemberdayaan Ekonomi Perempuan Melalui Grassroot Microfinance Syariah" Jurnal SAWWA - Volume 10, Nomor 1.

Rushayati B, Sunkar A, Hermawan R, Masganti, Meliani R. 2014. “Model Public Private Partnership dalam Mengatasi Degredasi dan Deforestasi Hutan.” Laporan Penelitian. Bogor: Fakultas Kehutanan IPB.
Riyadi dan Deddy., 2005., Perencanaan Pembangunan Daerah: Strategi Menggali Potensi dalam Mewujudkan Otonomi Daerah. Jakarta: Gramedia Pustaka Utama.

Soedjito, H. 2004. Pedoman Pengelolaan Cagar Biosfer. Jakarta: Komite Nasional MAB Indonesia.

Soetomo., 2011., Pemberdayaan Masyarakat: Mungkinkah Muncul Antitesisnya., Yogyakarta: Pustaka Pelajar.

Sujianto, dkk, 2016., Kajian Pengelolaan Kelembagaan Pemberdayaan Masyarakat Kawasan Cagar Biosfer Giam Siak Kecil-Bukit Batu di Provinsi Riau, LPPM Universitas Riau dan Balitbang Riau, Pekanbaru.

Sumaryadi, Nyoman., 2005., Perencanaan Pembangunan Daerah Otonom dan Pemberdayaan Masyarakat., Jakarta: Penerbit Citra Utama.

Syarif, Maryadi, 2013., Teori dan Model Pengembangan Kelembagaan Pendidikan Tinggi Islam., Jurnal Media Akademika, Vol. 28, No. 3.

Usman, Sunyoto. 2004., Pembangunan dan Pemberdayaan Masyarakat., Yogyakarta: Pustaka Pelajar.

Wasistiono, Sadu., 2007.,Prospek Pengembangan Desa., Bandung: Fokusmedia.,

Wrihatnolo, Randy R. dan Riant Nugroho Dwijowijoto., 2007., Manajemen Pemberdayaan: Sebuah Pengantar dan Panduan untuk Pemberdayaan Masyarakat., Jakarta: Elex Media Komputindo Gramedia. 